\title{
Combined Effects of Mugwort Herb and Vitamin C on Shelf-Life of Vacuum-Packed Seasoned Pork
}

\author{
Ko-Eun Hwang, Yun-Sang Choi ${ }^{1}$, Hyun-Wook Kim², Min-Sung Choi, Dong-Heon Song, \\ Yong-Jae Kim, Youn-Kyung Ham, and Cheon-Jei Kim* \\ Department of Food Science and Biotechnology of Animal Resources, Konkuk University, Seoul 143-701, Korea \\ ${ }^{1}$ Food Processing Research Center, Korean Food Research Institute, Seongnam 463-746, Korea \\ ${ }^{2}$ Meat Science and Muscle Biology Lab, Purdue University, West Lafayette, IN 47907, USA
}

\begin{abstract}
This study was performed to investigate the possibility of the addition of mugwort herb extract (MH) and vitamin C (VC) alone $(0.05 \%)$ and in combination $(0.05 \%$ each) on shelf-life of seasoned pork. The combination of $\mathrm{VC}+\mathrm{MH}$ demonstrated a significant reduction in thiobarbituric acid reactive substances, and volatile basic nitrogen in seasoned pork. Also, the pH values, total lactic acid concentration, lactic acid bacteria count, and the sensory properties (discoloration, flavor, and overall acceptability) of seasoned pork were not significantly affected by adding MH and/or VC. All seasoned pork were rejected by sensory panel when LAB count reached levels of 5$6 \mathrm{Log}$ CFU/g, TLA concentration has been above a level of 3.6-3.9 mg lactic acid/g, and pH values ranged from 5.31-5.51 (15 d). Therefore, the findings showed that spoilage of seasoned pork does not appear to be the result of lipid oxidation, but is caused by lactic acid producing bacteria which result in sour odor.
\end{abstract}

Keywords: mugwort, vitamin $\mathrm{C}$, shelf-life, seasoned meat, lactic acid bacteria

Received December 23, 2014; Revised February 26, 2015; Accepted March 5, 2015

\section{Introduction}

Quality deterioration of seasoned meat can be delayed using several techniques, various packaging methods, including vacuum packaging and modified atmosphere packaging (MAP), or low temperature, such as refrigerated storage condition. In meat processing industry, the application of highly effective antioxidants has become a popular and effective mean to extend the shelf-life of muscle foods (Seol et al., 2010). Low-cost synthetic antioxidants, such as tertbutylhydroquinone (TBHQ), butylated hydroxyanisole (BHA), and butylated hydroxyltoluen (BHT) have shown excellent antioxidant effects. However, synthetic antioxidants pose the possibility of health risk, toxicity, and carcinogenic effects (Cadun et al., 2008; Kim et al., 2013). For these reasons, replacements with more effective and non-toxic antioxidants are desired.

Mugwort (Artemisia princeps Pampanini) is a natural

\footnotetext{
*Corresponding author: Cheon-Jei Kim, Department of Food science and Biotechnology of Animal Resources, Konkuk University, Seoul 143-701, Korea. Tel: +82-2-450-3684, Fax: +822-444-6695, E-mail: kimcj@konkuk.ac.kr
}

herb plant used in tea, food, and traditional medicine in the East Asian countries such as Korea, Japan and China. In Korea, mugwort can be found in markets in various forms such as cakes, emulsified sausages, sauces, and noodles. Also, this plant contains bioactive compounds including phenolics, alkaloids, and vitamins $\mathrm{A}, \mathrm{B}_{1}, \mathrm{~B}_{2}$, and $\mathrm{C}$ as well as various minerals (Hwang et al., 2013).

Vitamin C (ascorbic acid; VC) is very effective not only for increasing shelf-life and stabilizing the color of meat and meat products but also for acting as a synergist when used in combination with other antioxidants by promoting their antioxidant effects. However, VC either promotes or inhibits lipid oxidation reactions in meat products depending on its concentration (Hwang et al., 2013).

To our knowledge, some studies have reported that the addition of functional ingredients, such as ginseng, pine needles, saponin, chitosan, propolis, medicinal plants, tomato powder, and kiwifruit increased shelf-life in seasoned meat products (Cho et al., 2002; Cho et al., 2007; Han et al., 2006; Kim and Kim, 2007; Kim et al., 2009; Lee et al., 2009; Youn et al., 2004). However, scientific literature on the shelf-life of seasoned pork meat added with antioxidant combination is still insufficient. Also,

(9)This is an open access article distributed under the terms of the Creative Commons Attribution Non-Commercial License (http://creativecommons.org/licences/ by-nc/4.0) which permits unrestricted non-commercial use, distribution, and reproduction in any medium, provided the original work is properly cited. 
the evaluation of their effect in a range of food systems is still needed on successful application in meat and meat products. Therefore, the objective of this study was to determine the effects of mugwort extracts $(\mathrm{MH})$ and vita$\min \mathrm{C}$ (VC) alone or in combination on the physicochemical, microbiological and sensory acceptance of seasoned pork during $20 \mathrm{~d}$ of storage at $4^{\circ} \mathrm{C}$.

\section{Materials and Methods}

\section{Preparation of mugwort extracts (MH)}

Commercial samples of dried mugwort were purchased from a local market on Ganghwa Island in Korea. After separating the leaves from the dried mugwort, they were ground using a blender (KA-2610, Jworld Tech, Korea) for $1 \mathrm{~min}$. Ten grams of ground leaves were mixed with $200 \mathrm{~mL}$ of $50 \%$ ethanol overnight ( $24 \mathrm{~h}$ ) in a shaker at room temperature. The extracts were filtered through filter paper No. 1 (Whatman International, UK) and then evaporated with a rotary evaporator (EYELA N-1000, Rikakikai, Japan) at $<50^{\circ} \mathrm{C}$. The concentrated product represented $\mathrm{MH}$.

\section{Preparation and processing of seasoned pork}

Fresh pork sirloin (M. longissimus dorsi), at $48 \mathrm{~h}$ postmortem, was purchased from a local market, and sliced into 0.4-cm thickness. An antioxidant combination of vitamin C (VC; Sewoo Inc, Korea) and mugwort extract (MH; pH, 6.14 $\pm 0.04 ; \mathrm{L}^{*}$-value, 28.71 \pm 0.04 ; a*-value, $1.79 \pm 0.36 ; b^{*}$-value, $\left.0.86 \pm 0.13\right)$ was prepared according to the formulations: Control (no antioxidant added), VC (0.05\% VC), MH (0.05\% MH) and VC+MH (0.05\% VC $+0.05 \% \mathrm{MH})$. Seasoned pork sauce was prepared with the ingredients listed in Table 1. Sliced pork sirloin was marinated separately in prepared sauce with antioxidant for 30 min using the tumbler (MKR-150C, Ruhle GmbH., Germany). Then, seasoned pork was divided into 24 samples ( 4 treatments $\times 6$ storage) in smaller portion (about $200 \mathrm{~g}$ each) and placed in polyethylene bags, and vacuum packaged using vaccum packaging system (FJ-500XL, Fuji Tech, Korea). All samples were stored at $4{ }^{\circ} \mathrm{C}$ and evaluated after $0,3,5,10,15$, and $20 \mathrm{~d}$ of storage periods.

\section{pH}

The $\mathrm{pH}$ values were measured in a homogenate (UltraTurrax T25, Janke and Kunkel, Germany) prepared with $5 \mathrm{~g}$ of sample and distilled water $(20 \mathrm{~mL})$ using a $\mathrm{pH}$ meter (Model 340, Mettler-Toledo GmbH, Switzerland). The $\mathrm{pH}$ meter calibrated with standard 4.00, 7.02, and 10.05
Table 1. Seasoned pork formulations with mugwort herb (MH) and vitamin $\mathrm{C}$ (VC)

\begin{tabular}{ccccc}
\hline \hline \multirow{2}{*}{ Ingredients (\%) } & \multicolumn{4}{c}{ Treatments $^{1)}$} \\
\cline { 2 - 5 } & Control & VC & MH & VC+MH \\
\hline Pork loin & 96 & 96 & 96 & 96 \\
Ice & 4 & 4 & 4 & 4 \\
\hline Total & 100 & 100 & 100 & 100 \\
\hline Soy sauce & 6 & 6 & 6 & 6 \\
Sugars & 2.5 & 2.5 & 2.5 & 2.5 \\
Green onion & 2 & 2 & 2 & 2 \\
Garlic & 2 & 2 & 2 & 2 \\
Onion juice & 12 & 12 & 12 & 12 \\
Black pepper & 0.05 & 0.05 & 0.05 & 0.05 \\
Sesame oil & 0.5 & 0.5 & 0.5 & 0.5 \\
Starch syrup & 1.7 & 1.7 & 1.7 & 1.7 \\
Sesame & 0.3 & 0.3 & 0.3 & 0.3 \\
Vitamin C (VC) & - & 0.05 & - & 0.05 \\
Mugwort herb extract (MH) & - & - & 0.05 & 0.05
\end{tabular}

${ }^{1)}$ Control: no antioxidant, $\mathrm{VC}$ : vitamin $\mathrm{C} 0.05 \%$, MH 0.2: mugwort herb extract $0.05 \%, \mathrm{VC}+\mathrm{MH}$ : vitamin $\mathrm{C} 0.05 \%$ and mugwort herb extract $0.05 \%$.

$\mathrm{pH}$ buffers (VWR Scientific Products) at a temperature of $20 \pm 1^{\circ} \mathrm{C}$. All determinations were performed in triplicate.

\section{Total lactic acid (TLA)}

TLA concentration was determined according to the Valli et al. (2006) using Megazyme kit (Megazyme International Ltd., Ireland). Briefly, each ground sample (5 g) was blended using homogenizer (AM-7, Nihonseiki, Kaisha Ltd., Japan) with $20 \mathrm{~mL}$ of $1 \mathrm{M}$ perchloric acid for 5 min and then transferred to a beaker. The solution was added $40 \mathrm{~mL}$ of distilled water and adjusted the $\mathrm{pH}$ to approx. 10.0 with $2 \mathrm{M} \mathrm{KOH}$, using $\mathrm{pH}$ meter (Model 340, Mettler-Toledo GmbH, Switzerland). Then, the solution was transferred quantitatively to a $100 \mathrm{~mL}$ volumetric flask and filled to the mark with distilled water. The solution was placed in a refrigerator for $20 \mathrm{~min}$ to allow separation of fat and precipitation of potassium perchlorate. The sample was filtered through filter paper No. 1 (Whatman International, UK). After filtration, concentrations of TLA in the supernatant were measured with the D-lactic acid and L-lactic acid kit and expressed as miligrams per gram $(\mathrm{mg} / \mathrm{g})$ of seasoned meat. The absorbance at $340 \mathrm{~nm}$ was read in a UV/VIS spectrophotometer (Optizen 2120 UV plus, Mecasys Co. Ltd., Korea).

\section{Volatile basic nitrogen (VBN) content}

VBN content was determined by the Conway microdiffusion method (Kohsaka, 1975), and was express as $\mathrm{mg} \%$ of the sample using the following steps: $5 \mathrm{~g}$ of each 
sample was mixed with $15 \mathrm{~mL}$ of distilled water for 1 min, and distilled water was added to bring the volume up to the final $50 \mathrm{~mL}$ followed by filtering through Whatman paper (No. 1). One milliliter of filtrate was placed in outer space of Conway unit, and $1 \mathrm{~mL}$ of $0.01 \mathrm{~N} \mathrm{H}_{3} \mathrm{BO}_{3}$ and $200 \mu \mathrm{L}$ of Conway reagent $(0.066 \%$ methyl red in ethanol : $0.066 \%$ bromocresol green in ethanol $=1: 1$ ) were added in inner space. The Conway unit was sealed immediately after adding $1 \mathrm{~mL}$ of $50 \% \mathrm{~K}_{2} \mathrm{CO}_{3}$ to the outer space. The sealed Conway unit was shaken slowly and incubated at $37^{\circ} \mathrm{C}$ for $2 \mathrm{~h}$. Then, $0.02 \mathrm{~N} \mathrm{H}_{2} \mathrm{SO}_{4}$ was added to inner space for titration. The VBN content was calculated using the following equation.

$$
\mathrm{VBN} \mathrm{mg} \%=\frac{(a-b) \times f \times 28.014 \times 100}{S}
$$

Where, $\mathrm{S}=$ the sample weight in gram, $\mathrm{a}=$ the volume (mL) of added $\mathrm{H}_{2} \mathrm{SO}_{4}$ in sample, $\mathrm{b}=$ the volume $(\mathrm{mL})$ of added $\mathrm{H}_{2} \mathrm{SO}_{4}$ in blank, $f$ the standard factor of $\mathrm{H}_{2} \mathrm{SO}_{4}$.

\section{Thiobarbituric acid reactive substances (TBARS) value}

Lipid oxidation was assessed in triplicate using the TBARS method of Tarladgis et al. (1960) with minor modifications and was expressed as miligrams of malondialdehyde (MD) per kilogram of seasoned pork. A 10-g sample was blended using homogenizer (AM-7, Nihonseiki, Kaisha Ltd., Japan) with $50 \mathrm{~mL}$ distilled water for $2 \mathrm{~min}$ and then transferred to a distillation tube. The cup used for blending was washed with an additional $47.5 \mathrm{~mL}$ of distilled water and added to the same distillation flask with $2.5 \mathrm{~mL}$ of $4 \mathrm{~N} \mathrm{HCl}$ and a few drops of antifoaming agent (KMK-73, Shin-Etsu Silicone Co., Ltd., Korea). The mixture was distilled, and $50 \mathrm{~mL}$ of the distillate was collected. Five milliliter of $0.02 \mathrm{M}$ TBA in $90 \%$ acetic acid (TBA reagent) was added to each test tubes containing $5 \mathrm{~mL}$ of the distillate and mixed well. The tubes were capped and heated in a boiling water bath for $30 \mathrm{~min}$ to develop the chromogen and cooled to room temperature. Absorbance was measured at $538 \mathrm{~nm}$ against a blank prepared with $5 \mathrm{~mL}$ distilled water and $5 \mathrm{~mL}$ TBA reagent using a UV/VIS spectrophotometer (Optizen 2120 UV plus, Mecasys Co. Ltd., Korea).

\section{Microbial analysis}

For all microbial counts, $25 \mathrm{~g}$ of samples were weighed and transferred into a sterile stomacher bag containing $225 \mathrm{~mL}$ of $0.1 \%$ peptone water followed by pummeling samples in a stomacher (Masticater-Paddle-Blender, IUL
Instrument, Spain) for $2 \mathrm{~min}$. From the prepared dilutions, total viable count (TVC), and lactic acid bacteria (LAB) count, total coliform bacteria count (TCC) and total Enterobacteriaceae count (TEC) were carried out. Plate Count Agar (PCA; Difco, USA) was used for TVC with an incubation period of $37^{\circ} \mathrm{C}$ for $2 \mathrm{~d}$. Lactobacilli MRS agar (Difco, USA) was used for LAB with an incubation period of $35^{\circ} \mathrm{C}$ for $2 \mathrm{~d}$. Escherichia coli/coliform count plate petrifilm and Enterobacteriaceae count plate petrifilm (3M Healthcare, USA) were used for TCC and TEC, respectively, with an incubation period of $35^{\circ} \mathrm{C}$ for $1 \mathrm{~d}$ under the same aerobic conditions.

\section{Sensory evaluation}

The seasoned pork samples were evaluated by 60 panelists (32 females, 28 males; aged 20-30) representing graduate students and members of the Department of Food Sciences and Biotechnology of Animal Resources, Konkuk University. Panellists were informed according to methodology proposed by ISO regulations (KS Q ISO, 2003; KS Q ISO, 2009) with the attributes and the scale to be used. Seasoned pork were cooked using a convection oven (Convotherm, OES6.06, Germany) at about $170^{\circ} \mathrm{C}$ for $5 \mathrm{~min}$. Each sample was served immediately after cooking. The attributes which have been studied are the following: discoloration, flavor, and overall acceptability using a 9-point hedonic rating scale (Lawless and Heymann, 1999). The scale includes the following ranking: $1=$ extremely unacceptable, $2=$ =ery much unacceptable, $3=$ moderately unacceptable, $4=$ slightly unacceptable, $5=$ between acceptable and unacceptable, $6=$ slightly acceptable, $7=$ moderately acceptable, $8=$ very much acceptable and $9=$ extremely acceptable. A mean score of 7 or above indicates an acceptable product. A mean score below 5.0 marks the end of seasoned pork shelf-life (Mexis et al., 2009). Water was provided to panelists to cleanse the palate between samples.

\section{Statistical analysis}

All data were subjected to the analysis of variance (ANOVA) using general linear model (GLM) procedure of SPSS 18.0 software (SPSS Inc., USA), with three replications, which was used as the storage periods (days 0 , $3,5,10,15$, and 20) and antioxidant type (Control, VC, $\mathrm{MH}, \mathrm{VC}+\mathrm{MH})$. When significant $(p<0.05)$ treatment effects were shown, Duncan's multiple range test was used to compare the mean values. Mean values and standard error of the means (SEM) were reported. The relationship between the $\mathrm{pH}$ and the TLA concentration is essentially 
linear and a standard linear regression model was used to describe it (Korkeala et al., 1990).

\section{Results and Discussion}

\section{VBN and TBARS values}

The VBN value is a good indicator of protein deterioration and decomposition in meat products freshness during storage periods (Choi et al., 2011). The influence of different antioxidant added on VBN content of seasoned pork is shown in Table 2. According to the results, $\mathrm{MH}$ or $\mathrm{VC}$ alone did not significantly affect the VBN content, whereas a significant effect from the storage time was noted $(p<0.05)$. Similar results were observed in seasoned pork formulated with yellow dock extracts $(0,1,3 \%)$, where the VBN content was not differ significantly (Kim et al., 2010). However, VC+MH had a little effect on inhibiting the increase in VBN content in seasoned pork than the other treatments $(p<0.05)$ from day 5 . The finding may be associated with synergistic effects $\mathrm{MH}$ and VC which inhibit proteolysis carried out by microorganisms and enzymes in meat products. SPISLP (2011) suggested that a VBN value of $20 \mathrm{mg} \%$ can be used as a threshold value to evaluate the degree of freshness of raw and packed meat. Kim et al. (2012) reported that many meat products do not decay, though their VBN content is $30 \mathrm{mg} \%$. In this study,
VBN contents in seasoned pork did not exceed this range during the 20-d storage period $(p<0.05)$.

The TBARS values represent the contents of secondary products as measured by MD contents and are illustrated in Table 2. As the storage period progressed, the TBARS values increased significantly $(p<0.05)$ in all samples. However, TBARS values were significantly lower at any day of storage in samples containing $\mathrm{VC}+\mathrm{MH}$, so TBARS formation was almost totally inhibited. This finding is in agreement with that of Turp and Serdarogu (2004), who noted that chicken patty treated with an antioxidant mixture (vitamin C 500 ppm and $\alpha$-tocopherol 200 ppm) was the most resistant to lipid oxidation, as evidenced by the lowest TBARS values compared with the other treatments. The results showed that antioxidant combination would more effectively inhibit lipid oxidation than using them alone during storage periods. Furthermore, Sheard et al. (2000) recommended a TBARS value of $0.5 \mathrm{mg} / \mathrm{kg}$ as a threshold value for rancidity perception by consumers. The TBARS values of all seasoned pork samples did not exceed $0.5 \mathrm{mg} / \mathrm{kg}$ by the end of the storage period.

\section{pH values and total lactic acid contents}

The $\mathrm{pH}$ is a dependable indicator of food stability and is associated with microbial and chemical reactions that cause food deterioration. The changes in $\mathrm{pH}$ value of sea-

Table 2. Changes in TBARS values (mg MD/kg) and VBN (mg\%) of seasoned pork containing different antioxidant during refrigerated storage for $20 \mathrm{~d}$

\begin{tabular}{|c|c|c|c|c|c|c|}
\hline \multirow{2}{*}{ Traits $^{1)}$} & \multirow{2}{*}{ Storage time (d) } & \multicolumn{5}{|c|}{ Treatments $^{21}$} \\
\hline & & Control & $\mathrm{VC}$ & MH & $\mathrm{VC}+\mathrm{MH}$ & SEM $^{3}$ \\
\hline \multirow{6}{*}{$\begin{array}{c}\text { TBARS } \\
(\mathrm{mg} \mathrm{MD} / \mathrm{kg})\end{array}$} & 0 & $0.18^{\mathrm{Ca}}$ & $0.19^{\mathrm{Ca}}$ & $0.16^{\mathrm{Ba}}$ & $0.15^{\mathrm{Aa}}$ & 0.003 \\
\hline & 3 & $0.22^{\mathrm{Cb}}$ & $0.22^{\mathrm{Cb}}$ & $0.19^{\mathrm{Bb}}$ & $0.17^{\mathrm{Ab}}$ & 0.004 \\
\hline & 5 & $0.30^{\mathrm{Dc}}$ & $0.27^{\mathrm{Cc}}$ & $0.23^{\mathrm{Bc}}$ & $0.20^{\mathrm{Ac}}$ & 0.006 \\
\hline & 10 & $0.36^{\mathrm{Dd}}$ & $0.32^{\mathrm{Cd}}$ & $0.28^{\mathrm{Bd}}$ & $0.24^{\mathrm{Ad}}$ & 0.006 \\
\hline & 15 & $0.40^{\mathrm{De}}$ & $0.37^{\mathrm{Ce}}$ & $0.33^{\mathrm{Be}}$ & $0.28^{\mathrm{Ae}}$ & 0.006 \\
\hline & 20 & $0.44^{\mathrm{Cf}}$ & $0.43^{\mathrm{Cf}}$ & $0.40^{\mathrm{Bf}}$ & $0.35^{\mathrm{Af}}$ & 0.005 \\
\hline \multicolumn{2}{|c|}{ SEM $^{3)}$} & 0.009 & 0.008 & 0.008 & 0.007 & \\
\hline \multirow{6}{*}{$\begin{array}{c}\text { VBN } \\
(\mathrm{mg} \%)\end{array}$} & 0 & $13.17^{\mathrm{Aa}}$ & $13.38^{\mathrm{Aa}}$ & $13.45^{\mathrm{Aa}}$ & $13.10^{\mathrm{Aa}}$ & 0.087 \\
\hline & 3 & $13.94^{\mathrm{Ab}}$ & $13.80^{\mathrm{Ab}}$ & $13.69^{\mathrm{Aa}}$ & $13.38^{\mathrm{Aa}}$ & 0.095 \\
\hline & 5 & $13.99^{\mathrm{Bb}}$ & $13.82^{\mathrm{Bb}}$ & $13.83^{\mathrm{Ba}}$ & $13.40^{\mathrm{Aa}}$ & 0.075 \\
\hline & 10 & $14.55^{\mathrm{Bc}}$ & $14.42^{\mathrm{Bc}}$ & $14.54^{\mathrm{Bb}}$ & $14.02^{\mathrm{Ab}}$ & 0.076 \\
\hline & 15 & $14.56^{\mathrm{Bc}}$ & $14.59^{\mathrm{Bc}}$ & $14.84^{\mathrm{Bb}}$ & $14.12^{\mathrm{Ab}}$ & 0.081 \\
\hline & 20 & $15.32^{\mathrm{Bd}}$ & $15.36^{\mathrm{Bd}}$ & $15.55^{\mathrm{Bc}}$ & $14.79^{\mathrm{Ac}}$ & 0.080 \\
\hline \multicolumn{2}{|c|}{$\mathrm{SEM}^{3)}$} & 0.108 & 0.109 & 0.123 & 0.102 & \\
\hline
\end{tabular}

${ }^{1)}$ Traits: TBARS, thiobarbituric acid reactive substances, VBN: volatile basic nitrogen.

${ }^{2)}$ Control: no antioxidant, $\mathrm{VC}$ : vitamin $\mathrm{C} 0.05 \%$, MH 0.2 : mugwort herb extract $0.05 \%$, VC+MH: vitamin $\mathrm{C} 0.05 \%$ and mugwort herb extract $0.05 \%$.

${ }^{3)}$ SEM: standard error of the means $(\mathrm{n}=12)$.

Means with different superscripts are significantly different $(p<0.05)$.

A-D antioxidant effects.

${ }^{\mathrm{a}-\mathrm{f}}$ storage day effects. 
Table 3. Changes in $\mathrm{pH}$ values, lactic acid concentration $(\mathrm{mg} / \mathrm{g})$, and microbial analysis of seasoned pork containing different antioxidant during refrigerated storage for $20 \mathrm{~d}$

\begin{tabular}{|c|c|c|c|c|c|c|}
\hline \multirow{2}{*}{ Traits $^{1)}$} & \multirow{2}{*}{ Storage time (d) } & \multicolumn{4}{|c|}{ Treatments $^{2)}$} & \multirow{2}{*}{$\mathrm{SEM}^{3}$} \\
\hline & & Control & $\mathrm{VC}$ & MH & $\mathrm{VC}+\mathrm{MH}$ & \\
\hline \multirow{6}{*}{$\mathrm{pH}$ values } & 0 & $5.52^{\mathrm{e}}$ & $5.51^{\mathrm{e}}$ & $5.53^{\mathrm{e}}$ & $5.52^{\mathrm{e}}$ & 0.004 \\
\hline & 3 & $5.52^{\mathrm{e}}$ & $5.49^{\mathrm{e}}$ & $5.52^{\mathrm{e}}$ & $5.51^{\mathrm{e}}$ & 0.004 \\
\hline & 5 & $5.45^{\mathrm{d}}$ & $5.42^{\mathrm{d}}$ & $5.45^{\mathrm{d}}$ & $5.43^{\mathrm{d}}$ & 0.005 \\
\hline & 10 & $5.38^{\mathrm{c}}$ & $5.37^{\mathrm{c}}$ & $5.37^{\mathrm{c}}$ & $5.37^{\mathrm{c}}$ & 0.004 \\
\hline & 15 & $5.32^{\mathrm{b}}$ & $5.30^{\mathrm{b}}$ & $5.31^{\mathrm{b}}$ & $5.30^{\mathrm{b}}$ & 0.004 \\
\hline & 20 & $5.20^{\mathrm{a}}$ & $5.19^{\mathrm{a}}$ & $5.21^{\mathrm{a}}$ & $5.18^{\mathrm{a}}$ & 0.003 \\
\hline \multicolumn{2}{|c|}{$\mathrm{SEM}^{3)}$} & 0.012 & 0.121 & 0.012 & 0.012 & \\
\hline \multirow{6}{*}{ TLA (mg/g) } & 0 & $2.6^{\mathrm{Ae}}$ & $2.6^{\mathrm{Ae}}$ & $2.6^{\mathrm{Ae}}$ & $2.6^{\mathrm{Ae}}$ & 0.013 \\
\hline & 3 & $2.7^{\mathrm{Ae}}$ & $2.7^{\mathrm{Ae}}$ & $2.7^{\mathrm{Ae}}$ & $2.7^{\mathrm{Ae}}$ & 0.018 \\
\hline & 5 & $3.0^{\mathrm{Ad}}$ & $3.0^{\mathrm{Ad}}$ & $3.0^{\mathrm{Ad}}$ & $2.8^{\mathrm{Bd}}$ & 0.028 \\
\hline & 10 & $3.2^{\mathrm{Ac}}$ & $3.2^{\mathrm{Ac}}$ & $3.2^{\mathrm{Ac}}$ & $3.0^{\mathrm{Bc}}$ & 0.033 \\
\hline & 15 & $3.9^{\mathrm{Ab}}$ & $3.9^{\mathrm{Ab}}$ & $3.9^{\mathrm{Ab}}$ & $3.6^{\mathrm{Bb}}$ & 0.027 \\
\hline & 20 & $5.2^{\mathrm{Aa}}$ & $5.1^{\mathrm{Aa}}$ & $4.8^{\mathrm{Ba}}$ & $4.6^{\mathrm{Ca}}$ & 0.052 \\
\hline \multicolumn{2}{|c|}{ SEM $^{4)}$} & 0.148 & 0.145 & 0.129 & 0.119 & \\
\hline \multirow{6}{*}{ LAB (CFU/g) } & 0 & $3.4^{\mathrm{a}}$ & $3.5^{\mathrm{a}}$ & $3.5^{\mathrm{a}}$ & $3.4^{\mathrm{a}}$ & 0.057 \\
\hline & 3 & $3.7^{\mathrm{a}}$ & $3.8^{\mathrm{a}}$ & $3.6^{\mathrm{a}}$ & $3.7^{\mathrm{a}}$ & 0.075 \\
\hline & 5 & $4.8^{\mathrm{b}}$ & $4.9^{\mathrm{b}}$ & $4.8^{\mathrm{b}}$ & $4.7^{\mathrm{b}}$ & 0.061 \\
\hline & 10 & $5.2^{\mathrm{b}}$ & $5.2^{\mathrm{b}}$ & $5.0^{\mathrm{b}}$ & $4.8^{\mathrm{b}}$ & 0.125 \\
\hline & 15 & $5.8^{\mathrm{c}}$ & $6.1^{\mathrm{c}}$ & $5.9^{\mathrm{c}}$ & $5.8^{\mathrm{c}}$ & 0.082 \\
\hline & 20 & $7.2^{\mathrm{d}}$ & $7.2^{\mathrm{d}}$ & $7.1^{\mathrm{d}}$ & $7.0^{\mathrm{d}}$ & 0.101 \\
\hline \multicolumn{2}{|c|}{$\mathrm{SEM}^{5)}$} & 0.228 & 0.225 & 0.215 & 0.225 & \\
\hline \multirow{6}{*}{ TVC (CFU/g) } & 0 & $4.4^{\mathrm{a}}$ & $4.4^{\mathrm{a}}$ & $4.4^{\mathrm{a}}$ & $4.3^{\mathrm{a}}$ & 0.123 \\
\hline & 3 & $4.4^{\mathrm{a}}$ & $4.6^{\mathrm{a}}$ & $4.5^{\mathrm{a}}$ & $4.5^{\mathrm{a}}$ & 0.093 \\
\hline & 5 & $5.1^{\mathrm{b}}$ & $5.2^{\mathrm{b}}$ & $5.1^{\mathrm{b}}$ & $5.1^{\mathrm{b}}$ & 0.043 \\
\hline & 10 & $5.5^{\mathrm{b}}$ & $5.4^{\mathrm{b}}$ & $5.5^{\mathrm{b}}$ & $5.4^{\mathrm{b}}$ & 0.057 \\
\hline & 15 & $6.0^{c}$ & $6.0^{\mathrm{c}}$ & $6.0^{\mathrm{c}}$ & $5.9^{\mathrm{c}}$ & 0.048 \\
\hline & 20 & $7.7^{\mathrm{d}}$ & $7.7^{\mathrm{d}}$ & $7.6^{\mathrm{d}}$ & $7.4^{\mathrm{d}}$ & 0.064 \\
\hline \multicolumn{2}{|c|}{ SEM $^{5}$} & 0.199 & 0.196 & 0.192 & 0.184 & \\
\hline
\end{tabular}

${ }^{1}$ Traits: TLA, total lactic acid concentration, LAB: lactic acid bacteria, TVC: total viable count.

${ }^{2)}$ Control: no antioxidant, VC: vitamin $\mathrm{C} 0.05 \%$, MH 0.2: mugwort herb extract $0.05 \%$, VC+MH: vitamin $\mathrm{C} 0.05 \%$ and mugwort herb extract $0.05 \%$.

${ }^{3)}$ SEM: standard error of the means $(n=9)$.

${ }^{4)}$ SEM: standard error of the means $(n=6)$.

${ }^{5)}$ SEM: standard error of the means $(\mathrm{n}=9)$.

Means with different superscripts are significantly different $(p<0.05)$.

$\mathrm{A}, \mathrm{B}$ antioxidant effects.

${ }^{\mathrm{a}-\mathrm{d}}$ storage day effects.

soned pork were not affected by the antioxidants (MH and/or VC), whereas storage time had a significant effect (Table 3). As storage time progressed from 0 to $20 \mathrm{~d}$, the $\mathrm{pH}$ values of all treatments decreased gradually from 5.51 to 5.18. Aksu and Kaya (2005) observed that the $\mathrm{pH}$ values were not significantly influenced by antioxidant addition. Also, Korkeala et al. (1990) noted that decrease in $\mathrm{pH}$ during storage was due to lactic acid generation by microorganisms.

The TLA of control and all the treated raw samples ranged from 2.6 to $2.7 \mathrm{mg} / \mathrm{g}$ with counts increasing from 4.6 to $5.2 \mathrm{mg} / \mathrm{g}$ after $20 \mathrm{~d}$ (Table 3). Korkeala et al. (1990) recommended that lactic acid could be used as an indica- tor of spoilage of meat products. If the TLA concentration is over $4 \mathrm{mg} / \mathrm{g}$ or $\mathrm{pH}$ is below 5.8 the samples can be deemed spoiled. In addition, Nassos et al. (1983) suggested that ground beef containing TLA level greater than $7.3 \mathrm{mg} / \mathrm{g}$ of meat would likely be found unacceptable by odor evaluation.

The scatter diagram between TLA concentration and the $\mathrm{pH}$ values of seasoned pork is shown in Fig. 1. The equation was $\mathrm{pH}=5.853-0.137 \times$ TLA ( $1 \mathrm{mg}$ of TLA/ $\mathrm{g}$ lead to a drop of $0.14 \mathrm{pH}$ value). Included in the figure are $95 \%$ confidence limits for both predicted means and individual observation. These results are supported by the good correlation coefficients between $\mathrm{pH}$ and lactic acid 


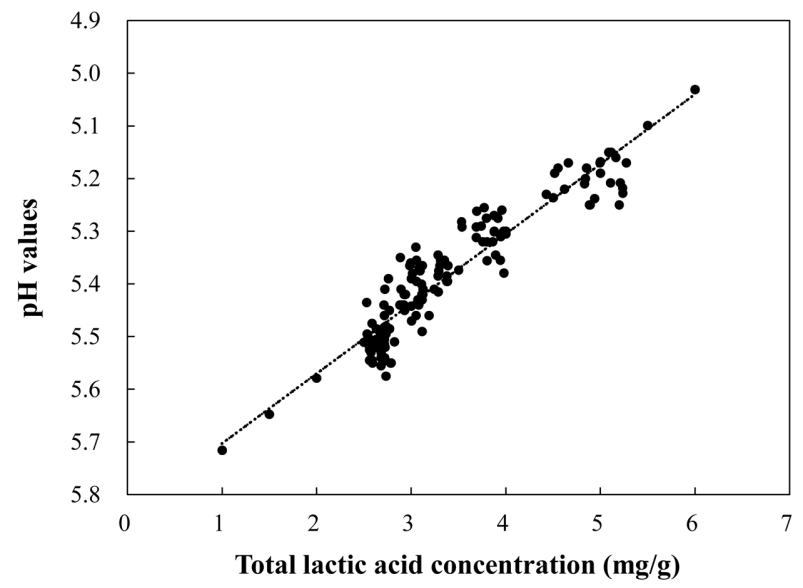

Fig. 1. The $\mathrm{pH}$ values as a function of lactic acid. $95 \%$ confidence limits for both predicted means (inner limits) and individual observations are included (The equation was pH $=5.8530 .137 \times$ total lactic acid)

concentration values. In this study, above a level of 3.6 $\mathrm{mg}$ lactic acid/g and $\mathrm{pH}$ values below 5.3, all samples were considered unacceptable as sensory panel noticed sour odor (15 d).

\section{Microbial analysis}

The effect of the addition of different antioxidant on microbial contents (LAB, TVC, TCC, TEC) during refriger- ated storage of seasoned pork is presented in Table 3, and Fig. 2, respectively.

The initial LAB of seasoned pork ranged from 3.4-3.5 Log CFU/g and it increased to 7.0-7.2 Log CFU/g after $20 \mathrm{~d}$. Similar trends in LAB were observed in studies by Fernandez-Lopez et al. (2005) who indicated that the growth of LAB was similar for control and treatments with rosemary oil and water extract during $12 \mathrm{~d}$ at $8^{\circ} \mathrm{C}$. According to Vermeiren et al. (2004), the sensory panel considered the rejected samples unfit for human consumption after LAB count reached levels of 7-8 Log CFU/g. In this research, the first evidence of sensory defects was an acidic odor, which occurred at a LAB of about 5-6 Log $\mathrm{CFU} / \mathrm{g}$ (15 d). Vermeiren et al. (2004) suggest that when stored under vacuum-packaging and refrigeration conditions, $\mathrm{LAB}$ will dominate the spoilage process. Because the metabolic activity of LAB results in spoilage appearing as sour, off-flavors, off-odors, slime production, swelling of the package through gas production, and discoloration such as greening.

The TVC of all samples were about 4.3-4.4 Log CFU/g, and significantly increased as storage progressed (Table 3). These data agree with the findings of Han et al. (2006), who noted that the microbial population on oriental medicinal seasoned pork added with propolis as being 3-4 Log CFU/g at day 0. Also, several authors have mentio-

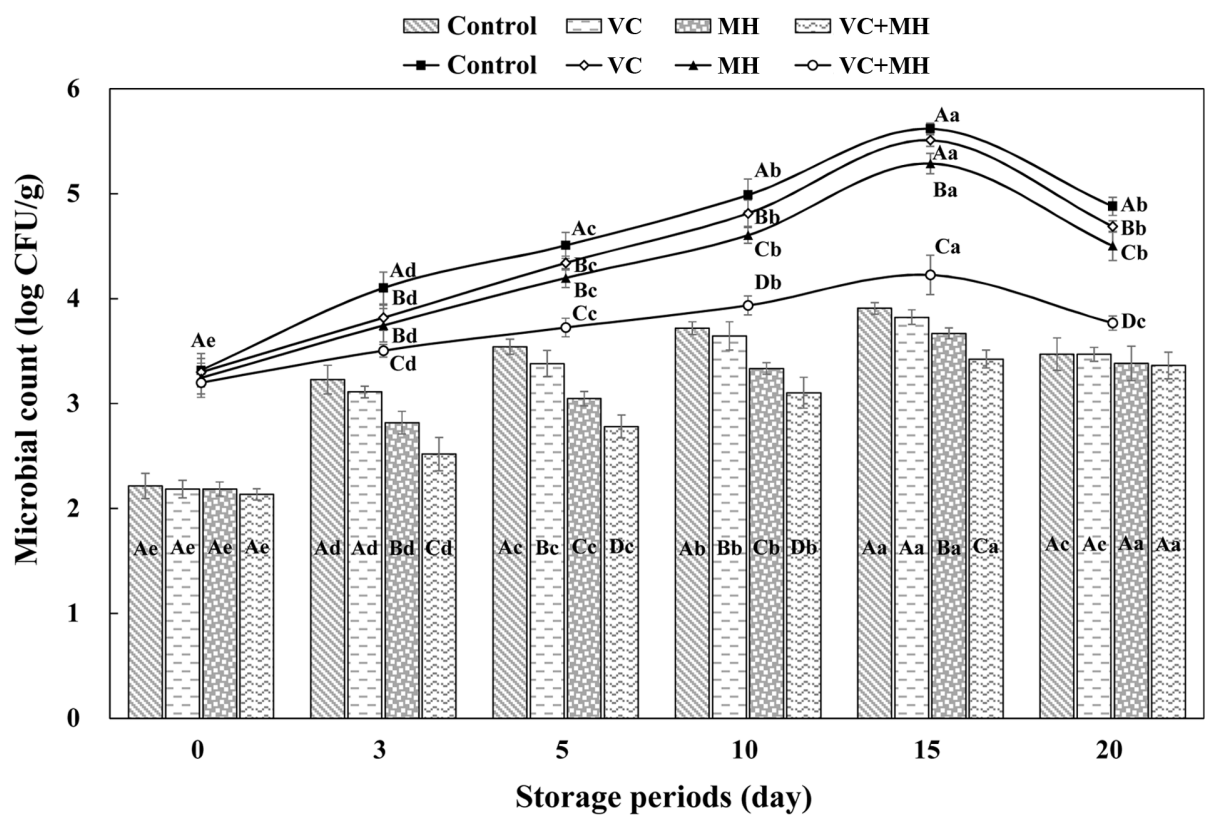

Fig. 2. Change in microbial $(\log C \mathrm{CU} / \mathrm{g})$ of seasoned pork containing different antioxidant during refrigerated storage for $20 \mathrm{~d}$. Control: no antioxidant, VC: vitamin C $0.05 \%$, MH 0.2: mugwort herb extract $0.05 \%$, VC+MH: vitamin $\mathrm{C} 0.05 \%$ and mugwort herb extract $0.05 \%$. 'Total coliform count: bar graph. ${ }^{2}$ Enterobacteriacea conut: line graph. Error bar represents the standard error of the mean for each treatment. Means with different superscripts are significantly different $(p<0.05) .{ }^{\mathrm{A}-\mathrm{D}}$ antioxidant effects. ${ }^{\mathrm{a}-\mathrm{e}}$ storage day effects. 
ned that the addition of functional ingredients to seasoned meat inhibited the growth of TVC during refrigerated storage (Han et al., 2006; Kim et al., 2009; Youn et al., 2004). However, in this study, there was no significant difference between treatment containing control or $\mathrm{MH}$ (either alone with vitamin $C$ ) throughout the storage time $(p>0.05)$. As storage time progressed, increase in TVC and number of LAB showed a similar pattern. According to Mantis et al. (2007), the TVC and LAB count were in similar number when sensory defects were first detected in Greek sausage. They recommended that various sensory defects were associated with the up to TVC of about $8 \mathrm{Log}$ $\mathrm{CFU} / \mathrm{g}$.

The TCC and TEC of seasoned pork formulated with different antioxidant are given in Fig. 2. Among all treatments, $\mathrm{VC}+\mathrm{MH}$ effectively delayed both TCC and TEC growth during the whole periods of storage $(p<0.05)$. These results agree with that of Zhang et al. (2009), who obtained similar results when total coliform bacteria decreased significantly after adding mixed spice extracts (rosemary and liquorice) compared with control in emulsified sausage $(p<0.05)$. This trend of controlling TCC and TEC may be due to synergistic effect of the mugwort in combination with vitamin $\mathrm{C}$ on the inhibitory effect of growth. Karabegovic et al. (2011) noted that extracts of various mugworts possess antimicrobial activity and the differences in antimicrobial activities of various mugworts can result in differences in their qualitative and quantitative components, which may be attributed to different growth environment and extraction conditions. TCC and TEC of all samples increased steadily during the first 15 days of storage and decreased thereafter. The decrease population supports the view that the formation of organic acid by bacterial metabolism caused decrease in $\mathrm{pH}$, which may inhibit the coliform growth (Lee et al., 2009). These authors noted that the population of total coliform bacteria increased in seasoned pork treated with medicinal plants significantly on $15 \mathrm{~d}$, followed by a decrease thereafter. Signorini et al. (2006) found that lactic acid was the most efficient compound for controlling spoilage population such as enterobacteriaceae species, Pseudomonas spp., and B. thermosphacta of meat stored at refrigeration condition.

\section{Sensory evaluation}

The sensory values for seasoned pork containing differ-

Table 4. Changes in sensory evaluation of seasoned pork containing different antioxidant during refrigerated storage for $20 \mathrm{~d}$

\begin{tabular}{|c|c|c|c|c|c|c|}
\hline \multirow{2}{*}{ Traits $^{1)}$} & \multirow{2}{*}{ Storage time $(\mathrm{d})$} & \multicolumn{4}{|c|}{ Treatments $^{2)}$} & \multirow{2}{*}{$\mathrm{SEM}^{3)}$} \\
\hline & & Control & $\mathrm{VC}$ & $\mathrm{MH}$ & $\mathrm{VC}+\mathrm{MH}$ & \\
\hline \multirow{5}{*}{ Discoloration } & 0 & $8.14^{\mathrm{d}}$ & $8.19^{d}$ & $8.39^{d}$ & $8.25^{\mathrm{d}}$ & 0.057 \\
\hline & 3 & $7.94^{\mathrm{d}}$ & $8.00^{\mathrm{d}}$ & $8.08^{\mathrm{cd}}$ & $8.31^{\mathrm{d}}$ & 0.071 \\
\hline & 5 & $7.42^{\mathrm{c}}$ & $7.42^{\mathrm{c}}$ & $7.69^{c}$ & $7.58^{\mathrm{c}}$ & 0.064 \\
\hline & 10 & $6.92^{b}$ & $6.83^{b}$ & $6.86^{\mathrm{b}}$ & $6.81^{b}$ & 0.061 \\
\hline & 15 & $5.00^{\mathrm{a}}$ & $5.11^{\mathrm{a}}$ & $5.25^{\mathrm{a}}$ & $5.14^{\mathrm{a}}$ & 0.064 \\
\hline \multicolumn{2}{|c|}{$\mathrm{SEM}^{3)}$} & 0.101 & 0.098 & 0.105 & 0.103 & \\
\hline \multirow{5}{*}{ Flavor } & 0 & $8.17^{\mathrm{d}}$ & $8.25^{\mathrm{d}}$ & $8.31^{\mathrm{d}}$ & $8.36^{\mathrm{d}}$ & 0.061 \\
\hline & 3 & $8.00^{\mathrm{d}}$ & $8.03^{\mathrm{d}}$ & $7.78^{d}$ & $7.83^{\mathrm{d}}$ & 0.053 \\
\hline & 5 & $7.72^{\mathrm{c}}$ & $7.89^{c}$ & $7.86^{\mathrm{c}}$ & $7.94^{\mathrm{c}}$ & 0.049 \\
\hline & 10 & $6.91^{b}$ & $6.99^{\mathrm{b}}$ & $7.03^{b}$ & $7.08^{b}$ & 0.054 \\
\hline & 15 & $5.11^{\mathrm{a}}$ & $5.11^{\mathrm{a}}$ & $5.22^{\mathrm{a}}$ & $5.36^{\mathrm{a}}$ & 0.062 \\
\hline \multicolumn{2}{|c|}{$\mathrm{SEM}^{3)}$} & 0.096 & 0.098 & 0.103 & 0.097 & \\
\hline \multirow{5}{*}{$\begin{array}{c}\text { Overall } \\
\text { acceptability }\end{array}$} & 0 & $8.57^{d}$ & $8.65^{d}$ & $8.61^{\mathrm{d}}$ & $8.69^{d}$ & 0.054 \\
\hline & 3 & $8.22^{c}$ & $8.25^{\mathrm{c}}$ & $8.44^{\mathrm{c}}$ & $8.53^{c}$ & 0.046 \\
\hline & 5 & $7.98^{b}$ & $8.08^{b}$ & $8.11^{b}$ & $8.11^{b}$ & 0.059 \\
\hline & 10 & $6.55^{\mathrm{a}}$ & $6.49^{\mathrm{a}}$ & $6.53^{\mathrm{a}}$ & $6.72^{\mathrm{a}}$ & 0.048 \\
\hline & 15 & $4.96^{\mathrm{a}}$ & $4.96^{\mathrm{a}}$ & $5.19^{\mathrm{a}}$ & $5.23^{\mathrm{a}}$ & 0.046 \\
\hline \multicolumn{2}{|c|}{ SEM $^{3)}$} & 0.113 & 0.115 & 0.108 & 0.106 & \\
\hline
\end{tabular}

1) Sensory score: $1=$ extremely unacceptable, $2=$ very much unacceptable, $3=$ moderately unacceptable, $4=$ slightly unacceptable, $5=$ between acceptable and unacceptable, $6=$ slightly acceptable, $7=$ moderately acceptable, $8=$ very much acceptable and $9=$ extremely acceptable. A mean score of 7 or above indicates an acceptable product. A mean score below 5.0 marks the end of seasoned pork shelf-life.

${ }^{2)}$ Control: no antioxidant, VC: vitamin C $0.05 \%$, MH 0.2: mugwort herb extract $0.05 \%$, VC+MH: vitamin $\mathrm{C} 0.05 \%$ and mugwort herb extract $0.05 \%$.

${ }^{3}$ SEM: standard error of the means $(n=4)$.

Means with different superscripts are significantly different $(p<0.05)$.

${ }^{\mathrm{a}-\mathrm{d}}$ storage day effects. 
ent antioxidant are displayed in Table 4. Addition of $\mathrm{MH}$ and/or VC in seasoned pork did not significantly affect the sensory characteristics, whereas a significant effect from the storage time was noted $(p<0.05)$. These results are in accordance with that of Naveena et al. (2008), who reported that addition of pomegranate juice and rind powder in chicken patties did not impart a significant difference in sensory characters (off-odor, sweet-flavor, chicken flavor, or overall palatability score). As the storage time increased, sensory characters (discoloration, flavor, and overall acceptability) had lower scores than those of initial storage periods. In this study, sensory panel rejected the seasoned pork unfit for human consumption above a level of 3.6-3.9 mg lactic acid/g, LAB reached levels of 5-6 Log CFU/g, and $\mathrm{pH}$ values ranged from 5.31-5.51 (15 d). These results are in agree with that of Choi and Lee (2002), who reported that seasoned pork meat, which the LAB count increased with more than $7 \mathrm{Log} \mathrm{CFU} / \mathrm{g}$ and $\mathrm{pH}$ values decreased with less than 5.5, had rancid odors and off-flavors. Several authors have found no correlation between total LAB counts and sensory deterioration (Leroi, 2010; Leroi \& Joffraud, 2001). However, PaludanMüller et al. (1998) succeeded in increasing the shelf-life of cold-smoked salmon by inhibiting LAB with nisin, suggesting a possible spoiling effect of this bacterial group. The sensory deterioration due to functions of $\mathrm{LAB}$, the compounds responsible and their associated precursors have been summarized by Huss et al. (1995). The carbohydrate fermentation causes sour tastes and marinated offodors and flavors due to organic acid production (Leroi, 2010). Therefore, producing bacterial have been shown to be responsible for the spoilage of vacuum packed seasoned pork meat; a fermented, sour odor and taste are described as the main sensory defects.

\section{Conclusion}

An antioxidant mixture of $\mathrm{MH}$ and $\mathrm{VC}$ was effective in inhibiting lipid oxidation (TBARS formation) and microbial growth (TEC and TCC) in seasoned pork during refrigerated storage at $4^{\circ} \mathrm{C}$. Additionally, TLA concentration, LAB count, and the sensory properties (discoloration, flavor, and overall acceptability) of seasoned pork were not significantly affected by adding $\mathrm{MH}$ and/or VC. In this study, the increase in both LAB populations and TLA concentration, as well as decrease in the $\mathrm{pH}$ values, generally coincided with the sensory scores detected by the sensory panel. Further studies are needed to control LAB in vacuum packed seasoned meat, especially if combined with
$\mathrm{MH}$, which is capable of inhibiting the growth of lactic acid bacteria.

\section{Acknowledgements}

This research was supported by the Brain Korean 21 Plus (BK 21 Plus) Project from Ministry (Republic of Korea).

\section{References}

1. Aksu, M. I. and Kaya M. (2005) The effect of $\alpha$-tocopherol and butylated hydroxyanisole on the color properties and lipid oxidation of kavurma a cooked meat product. Meat Sci. 71, 277-283.

2. Cadun, A., Kişla, D., and Çakh, Ş. (2008) Marination of deep-water pink shrimp with rosemary extract and the determination of its shelf-life. Food Chem. 109, 81-87.

3. Calvert, J. T. and Decker, E. A. (1992) Interactions between carnosine and selected antioxidants in ground turkey. J. Food Qual. 15, 423-433.

4. Cho, H. S., Shin, J. H., Lee, S. J., Kang, M. J., Cho, H. S., and Sung, N. J. (2007) Lipid compositions changes of seasoned pork prepared with medicinal plant extracts during storage. J. Life Sci. 17, 1675-1681.

5. Cho, S. H., Park, B. Y., Yoo Y. M., Chae, H. S., Wyi, J. J., Ahn, C. N., Kim, J. H., Lee, J. M., Kim, Y. K., and Yun, S. G. (2002) Physico-chemical and sensory characteristics of pork bulgogi containing ginseng saponin. Korean J. Food Sci. An. 22, 30-36.

6. Choi, W. S. and Lee, K. T. (2002) Quality changes and shelflife of seasoned pork with soy sauce or Kochujang during chilled storage. Korean J. Food Sci. An. 22, 240-246.

7. Choi, Y. S., Choi, J. H., Kim, H. Y., Kim, H. W., Lee, M. A., Chung, H. J., Lee, S. K., and Kim, C. J. (2011) Effect of Lotus (Nelumbo nucifera) leaf powder on the quality characteristics of chicken patties in refrigerated storage. Korean J. Food Sci. An. 31, 9-18.

8. Fernandez-Lopez, J., Zhi, N., Aleson-Carbonell, L., PerezAlverez, J. A., and Kuri, V. (2005) Antioxidant and antibacterial activities of natural extracts: Application in beef meatballs. Meat Sci. 69, 371-380.

9. Han, G. J., Shin, D. S., Kim, J. S., Cho, Y. S., and Jeong, K. S. (2006) Effects of propolis addition on quality characteristics of oriental medicinal seasoning pork. Korean J. Food Sci. An. 38, $75-81$.

10. Huss, H. H., Jeppesen, V. F., Johansen, C., and Gram, L. (1995) Biopreservation of fish products a review of recent approaches and results. J. Aquat. Food Prod. Tech. 4, 5-26.

11. Hwang, K. E., Choi, Y. S., Choi, S. M., Kim, H. W., Choi, J. H., Lee, M. A., and Kim, C. J. (2013) Antioxidant action of ganghwayakssuk (Artemisia princeps Pamp.) in combination with ascorbic acid to increase the shelf-life in raw and deep fried chicken nuggets. Meat Sci. 95, 593-602.

12. Karabegović, I., Nikolova, M., Velièković, D., Stojièević, S., 
Veljković, V., and Lazić, M. (2011) Comparison of antioxidant and antimicrobial activities of methanolic extracts of the Artemisia sp. recovered by different extraction techniques. Chinese J. Chem. Eng. 19, 504-511.

13. Kim, C. R. and Kim, K. H. (2007) Quality evaluations of seasoning chicken containing pine needles during cold storage. Korean J. Food Sci. An. 27, 47-52.

14. Kim, H. J., Hwang, E. Y., Im, N. K., Park, S. K., and Lee, I. S. (2010) Antioxidant activities of Rumex crispus extracts and effects on quality characteristics of seasoned pork. Korean $J$. Food Sci. Technol. 42, 445-451.

15. Kim, I. S., Jin, S. K., Kang, S. N., Hur, I. C., and Choi, S. Y. (2009) Effect of olive-oil prepared tomato powder (OPTP) and refining lycopene on the physicochemical and sensory characteristics of seasoned raw pork during storage. Korean J. Food Sci. An. 29, 334-339.

16. Kim, S. J., Cho, A. R., and Han, J. (2013) Antioxidant and antimicrobial activities of leafy green vegetable extracts and their applications to meat product preservation. Food Control 29, 112-120.

17. Kim, Y. B., Ku, S. K., Joo, B. J., Lee, N. H., and Jang, A. (2012) Changes in nucleotide compounds, and chemical and sensory qualities of duck meat during aging at $0^{\circ} \mathrm{C}$. Korean J. Food Sci. An. 32, 428-433.

18. Kohsaka, K. (1975) Freshness preservation of food and measurement. Food Ind. 18, 105-111.

19. Korkeala, H., Alanko, T., Mäkelä, P., and Lindroth, S. (1990) Lactic acid and $\mathrm{pH}$ as indicators of spoilage for vacuumpacked cooked ring sausages. Int. J. Food Microbiol. 10, 245254.

20. KS Q ISO (2003) International standard 8586-1. Sensory analysis. General guidance for the selection, training and monitoring of assessors. Part 1: selected assessors. International Organization for Standardization.

21. KS Q ISO (2009) International standard 5496. Sensory analysis. Methodology. Initiation and training of assessors in the detection and recognition of odours. International Organization for Standardization.

22. Lawless, H. T. and Heymann, H. (1999) Sensory evaluation of food principles and practices. Springer Science + Business Media, NY, pp. 450-457.

23. Lee, S. H., Jeong, E. J., Jung, T. S., and Park, L. Y. (2009) Antioxidant activities of seasoning sauces prepared with Geranium thunbergii sieb. et Zucc. and Crataegi fructus and the quality changes of seasoned pork during storage. Korean J. Food Sci. Technol. 41, 57-63.

24. Leroi, F. (2010) Occurrence and role of lactic acid bacteria in seafood products. Food Microbiol. 27, 698-709.

25. Leroi, F., Joffraud, J. J., Chevalier, F., and Cardinal, M. (2001) Research of quality indices for cold-smoked salmon using a stepwise multiple regression of microbiological counts and physico-chemical parameters. J. Appl. Microbiol. 90, 578587.

26. Mantis, F., Burriel, A. R., Sabatakou, O., Vacalopoulos, A., and Ramantanis, R. (2007) Some factors determining the shelf-life of vacuum packed heat treated Greek sausages. Vet. Arhiv. 77, 229-235.

27. Mexis, S. F., Chouliara, E., and Kontominas, M. G. (2009) Combined effect of an $\mathrm{O}_{2}$ absorber and oregano essential oil on shelf-life extension of Greek cod roe paste (tarama salad) stored at $4^{\circ}$ C. Innov. Food Sci. Emerg. Tech. 4, 572-579.

28. Nassos, P. S., King, D., and Stafford, A. E. (1983) Relationship between lactic acid concentration and bacterial spoilage in ground beef. Appl. Environ. Microbiol. 46, 894-900.

29. Naveena, B, M., Sen, A. R., Vaithiyanathan, S., Babji, Y., and Kondaiah, N. (2008) Comparative efficacy of pomegranate juice, pomegranate rind powder extract and BHT as antioxidants in cooked chicken patties. Meat Sci. 80, 1304-1308.

30. Paludan-Müller, C., Dalgaard, P., Huss, H. H., and Gram, L. (1998) Evaluation of the role of carnobacterium piscicola in spoilage of vacuum and modified atmosphere-packed-smoked salmon stored at $5^{\circ}$ C. Int. J. Food Microbiol. 39, 155-166.

31. Seol, K. H., Seol, H. C., Prayad, T., Kim, H. W., Jang, A. R., Ham, J. S., Oh, M. H., Kim, D. H., and Lee, M. (2010) The effect of the water extracts of digestive medicinal plants on the shelf-life of pork patties. Korean J. Food Sci. An. 30, 780-786.

32. Sheard, P. R., Enser, M., Wood, J, D., Nute, G. R., Gill, B. P., and Richardson, R. I. (2000) Shelf-life and quality of pork and pork products with raised $n-3$ PUFA. Meat Sci. 55, 213-221.

33. Signorini, M. L., Ponce-Alquicira, E., and Guerrero-Legarreta, I. (2008) Effect of lactic acid and lactic acid bacteria on growth of spoilage microorganisms in vacuum-packaged beef. $J$. Muscle Foods 17, 277-290.

34. SPISLP (Standard for Processing and Ingredient Specifications of Livestock Product) (2011) Animal, Plant and Fisheries Quarantine and Inspection Agency (APFQIA), Korea, pp. 300-302.

35. Tarladgis, B. G., Watts, B. M., Younthan, M. T., and Dugan, L. R. (1960) A distillation method for the quantitative determination of malonaldehyde in rancid foods. J. Am. Oil Chem. Soc. 37, 403-406.

36. Turp, G. Y. and Serdaroglu, M. (2004) The Effects of ascorbic acid, rosemary extract and $\alpha$-tocopherol/ascorbic acid on some quality characteristics of chicken patties stored at $4^{\circ} \mathrm{C}$ for 7 Days. J. Food Technol. 2, 153-157.

37. Valli, M., Sauer, M., Branduardi, P., Borth, N., Porro, D., and Mattanovich, D. (2006) Improvement of lactic acid production in saccharomyces cerevisiae by cell Sorting for high intracellular pH. Am. Soc. Microbiol. 72,5492-5499.

38. Vermeiren, L., Devlieghere, F., and Debevere, J. (2004) Evaluation of meat born lactic acid bacteria as protective cultures for the biopreservation of cooked meat products. Int. J. Food Microbiol. 96, 149-164.

39. Youn, S. K., Choi, J. S., Park, S. M., and Ahn, D. H. (2004) Studies on the improvement of shelf-life and quality of vacuum-packaged seasoned pork meat by added chitosan during storage. J. Anim. Sci. Technol. 46, 1023-1030. 
40. Zhang, H., Kong, B. L., Xiong, Y. L., and Sun, X. (2009) Antimicrobial activities of spice extract against pathogenic and spoilage bacteria in modified atmosphere packaged fresh pork and vacuum packaged ham slices stored at $4^{\circ} \mathrm{C}$. Meat Sci. 81, 686-692. 